\title{
PENYULUHAN MOTIVASI DAN PENGEMBANGAN SDM UNTUK MENINGKATKAN KEMANDIRIAN WIRAUSAHA HOME INDUSTRY MEJA KURSI DARI BAN BEKAS
}

\author{
${ }^{1}$ Aden Prawiro Sudarso, ${ }^{2}$ H. San Ridwan Maulana, ${ }^{3}$ Yossi Wahyu \\ Indrawan, ${ }^{4}$ Akhmar Barsah, ${ }^{5}$ Sudiarto \\ Dosen Fakultas Ekonomi Universitas Pamulang \\ Email: dosen01171@unpam.ac.id
}

\begin{abstract}
ABSTRAK
Secara umum pelaku home industry yang menjadi permasalahan adalah motivasi berwirausaha, karena untuk menjadi wirausahawan tidak cukup hanya bermodalkan tekat menjadi wirausahawan tetapi butuh komitmen dan motivasi untuk menjadi wirausahawan, tujuan dari kegiatan pengabdian kepada masyarakat ini adalah untuk memberikan motivasi dan pengembangan SDM agar home industry dapat berkembang menjadi industry yang besar dimana dapat menyerap banyak tenaga kerja yang tentunya dapat mengurangi angka pengangguran. Selain itu juga untuk menggerakkan masyarakat sekitar agar termotivasi menjadi wirausaha yang mandiri.

Metode yang disampaikan adalah metode penyuluhan dengan pendekatan strategi pengembangan UMKM.

Hasil kegiatan ini diharapkan dapat meningkatkan motivasi dan pengembangan sumber daya manusianya agar dapat mengembangkan usahanya, sehingga mampu meningkatkan ekonomi masyarakat daerah sekitar. Daur ulang ban bekas menjadi meja kursi atau peralatan yang lain sebenarnya baru salah satu cohtoh pemanfaatan barang bekas, masih banyak yang bisa dilakukan dengan sentuhan kreatif merubah barang bekas menjadi barang bernilai ekonomis asalkan ada kemauan dan kemampuan untuk melakukannya.
\end{abstract}

\section{Kata Kunci: Motivasi, Kemandirian, Wirausaha}

\section{PENDAHULUAN}

Secara umum pelaku home industry yang menjadi permasalahan adalah motivasi berwirausaha, karena untuk menjadi wirausahawan tidak cukup hanya bermodalkan tekat menjadi wirausahawan tetapi butuh komitmen dan motivasi untuk menjadi wirausahawan. Karena untuk merintis usaha atau membuka usaha home indutry tidaklah semudah membalikan telapak tangan. Jatuh bangun dalam usaha itu hal yang sangat wajar, maka dari itu butuh sumber daya manusia yang berdedikasi, ulet, pantang menyerah, pekerja keras dan berani mengambil risiko. agar home industry nya tetap eksis. Karena home industry secara umum milik perorangan sehingga cenderung kurang komitmen dan kurang disiplin dalam mengelola usahanya. Hal ini yang menyebabkan perkembangan usaha pada home industry sulit diukur dan sulit berkembang karena secara struktur organisasi juga 
belum ada, besaran modal kurang jelas, terkadang modal berjalan, artinya jika dalam perjalanan usahanya kurang modal akan ditambah dengan sendirinya dari uang pribadi dan belum dilakukan pembukuan.

Obyek pada kegiatan pengabdian kepada masyarakat ini adalah home industry meja kursi dari ban bekas karena pengusul pengabdian kepada masyarakat home industry ini memiliki potensi untuk dikembangkan dan sangat prospektif. Dan harapannya masyarakat sekitar dapat mencontoh kreatifitas dan daya juangnya untuk mengubah barang bekas yang tidak bernilai secara ekonomis menjadi barang yang bernilai guna serta bernilai ekonomi tinggi. Meskipun tidak harus sama, bahan baku ban bekas tetapi motivasi berwirausaha dapat dikembangkan di masyarakat sekitarnya.

\section{METODE PELAKSANAAN KEGIATAN} berikut:

Adapun metode pelaksanaan program kemitraan masyarakat sebagai

1. Tahap Pemilihan Lokasi Pengabdian

Tahap pemilihan lokasi pengabdian kepada masyarakat tentu harus mempertimbangkan banyak hal., salah satunya adalah kebutuhan masyarakat yang merupakan objek dari pengabdian.

2. Tahap Pengusulan

Setelah tim pengusul melakukan observasi awal dan sudah mengidentifikasi permasalahan pada objek pengabdian kepada masyarakat, maka dapat ditentukan temanya atau judulnya.

3. Tahap Pengumpulan data

Pengumpulan data yaitu mengumpulkan data di lokasi pengabdian dengan melakukan konsultasi, observasi, wawancara, dan dokumentasi dengan menentukan strategi pengumpulan data yang dipandang tepat untuk menentukan tema atau fokus serta pendalaman data pada proses pengumpulan

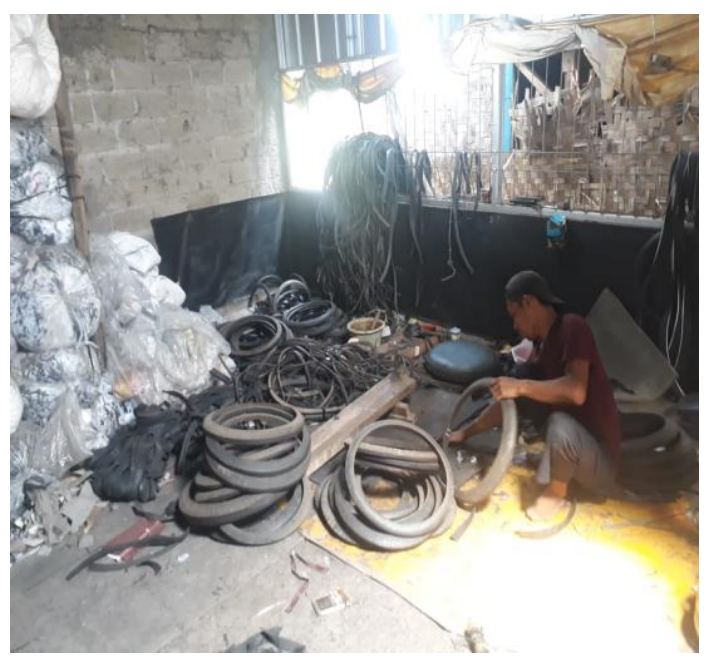
data berikutnya. Pada tahap pengumpulan data ini ditujukan untuk mengidentifikasi permasalahan yang dihadapai oleh pelaku home industry pembuat meja kursi dari ban bekas. Dari hasil survey dan wawancara dengan pemilik usaha home industry diperoleh data permasalahan bahwa dalam pengelolaan daur ulang ban bekas mengalami kendala di motivasi pekerja.

4. Tahap Persiapan Pelaksanaan Tahap persiapan ini, dilakukan koordinasi secara intensif dengan anggota (tim) agar pelaksanaan kegiatan pengabdian kepada 
masyarakat dapat berjalan lancar. Persiapan materi penyuluhan, menyiapkan pemateri/narasumber, persiapan konsumsi, daftar hadir dan perlengkapan lain yang dibutuhkan terkait pelaksanaan kegiatan. Setelah semua sudah siap tentu juga perlu konfirmasi pada pemilik home industry akan hari, tanggal dan waktu pelaksanaan

5. Tahap Pelaksanaan Pengabdian Kepada Masyarakat

Tahap pelaksanaan pengabdian kepada masyarakat merupakan tahap pelaksanaan penyuluhan tentang motivasi dan pengembangan SDM untuk meningkatkan kemandirian wirausaha home industry meja kursi dari ban bekas. Pada tahap ini tim pengusul melakukan penyuluhan sesuai tema terkait, melakukan sharing pendapat, dan mengidentifikasi kebutuhan materi yang diinginkan dan penawaran program pengabdian kepada masyarakat berkelanjutan di masa-masa yang akan datang.

6. Tahap Pelaporan Hasil Pengabdian

Pada tahan pelaporan hasil pengabdian kepada masyarakat ini merupakan laporan serangkaian kegiatan mulai dari surve pra pengabdian hingga pelaporan kegiatan.

7. Tahap Publikasi

Hasil atau laporan kegiatan pengabdian kepada masyarakat akan dipublikasikan agar dimanfaatkan sebagai referensi bagi penelitian atau kegiatan pengabdian kepada masyarakat di masa yang akan datang.

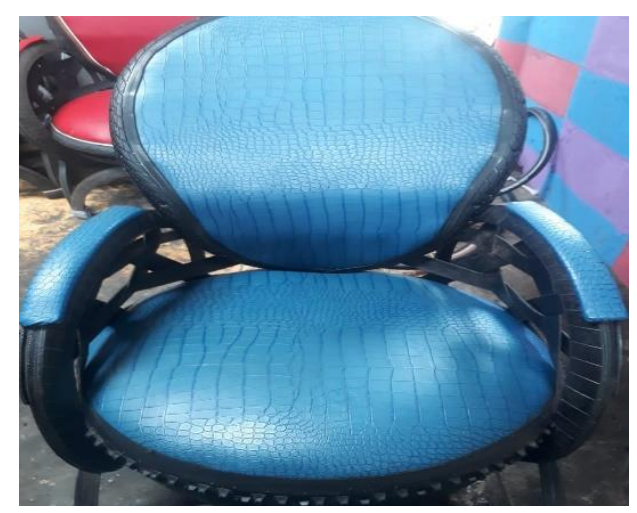

\section{HASIL DAN PEMBAHASAN}

Home industry daur ulang barang bekas mungkin belum familier di masyarakat, atau masih dipandang sebelah mata karena bahan bakunya dari barang bekas. Wajar kalau selama ini produk kreatifitas dari daur ulang barang bekas belum mendapatkan tempat di hati masyarakat. Untuk itu perlu mendapatkan perhatian dari pemerintah daerah setempat dan civitas akademika untuk membantu mengembangkan usahanya. Permasalahan yang biasa dihadapai bagi pelaku home industry yaitu: akses permodalan, pemasaran hasil produk dan sumberdaya manusia yang kompeten. Kebanyakan orang lebih memilih menjadi karyawan pabrik dari pada menjadi pekerja home industry apalagi mendaur ulang barang bekas. Sementara kualifikasi yang dimiliki untuk menjadi karyawan pabrik belum memenuhi syarat. Hal yang begini yang menyebabkan beertambahnya angka pengangguran.

Kegiatan pengabdian kepada masyarakat dari tim dosen Universitas Pamulang hadir ditengah-tengah masyarakat untuk membantu memberikan solusi permasalahan-permasalahan yang terjadi dalam bentuk penyuluhan motivasi dan pengembangan SDM untuk meningkatkan kemandirian wirausaha home industry 
meja kursi dari ban bekas hadir dengan harapan dapat meningkatkan motivasi dan pengembangan sumber daya manusianya agar dapat mengembangkan usahanya tidak sebatas menghasilkan 4 (empat) set dalam satu hari dengan dua pekerja, melainkan dapat menyerap tenaga kerja lebih banyak dan mampu memproduksi meja kursi dari ban lebih banyak, sehingga mampu meningkatkan ekonomi masyarakat daerah sekitar. Daur ulang ban bekas menjadi meja kursi atau peralatan yang lain sebenarnya baru salah satu cohtoh pemanfaatan barang bekas, masih banyak yang bisa dilakukan dengan sentuhan kreatif merubah barang bekas menjadi barang bernilai ekonomis asalkan ada kemauan dan kemampuan untuk melakukannya.

Daur ulang ban bekas ini sangat berpotensi untuk dikembangkan dan diarahkan menjadi ekonomi produktif, karena setelah mendapat sentuhan kreatifitas, ban bekas ini dapat disulap menjadi meja kursi yang tahan karat, awet dan nyaman, juga mempunyai peluang usaha yang prospektif. Hal ini dikarenakan bahwa ban yang berbahan baku dari karet mempunyai sifat anti karat, anti air dan lunak sehingga tidak berbahaya apabila ban bekas ini dijadikan mebeler rumah tangga seperti meja kursi, sofa, kursi goyang dan sejenisnya. Potensi usaha ini juga didukung oleh mudahnya memperoleh bahan baku ban bekas dengan harga yang relatif murah dan mudah didapat. Hal ini dikarenakan dengan kepadatan penduduk dengan volume kepemilikan kendaraan yang besar berpotensi penyediaan ban bekas tercukupi.

Tentu masing masing bahan baku mempunyai/dibutuhkan sesuai peran masing-masing, seperti ban dump truck diambil bagian dalamnya untuk anyaman baik sandaran atau bagian bawah dudukan, sementara ban sepeda motor biasa diperoleh dari pabrik ban motor yang rusak/cacat untuk dijadikan bingkai lingkaran kursi, meja dan sandaran kursi jadi tampak baru dan rapi. Semua digunakan dari bahan ban dan dirangkai dengan lem dan paku. Hampir semua bahan dari barang bekas (limbah) seperti busa untuk dudukan kursi diperoleh dari limbah pabrik busa atau springbed. Bisa juga dalamnya dudukan diisi ban yang tidak kepakai dipotong kecil-kecil, sedang yang benar-benar tidak digunakan bisa dijual untuk bahan bakar, jadi kesimpulannya tidak ada bahan yang tidak dapat dijadikan uang meskipun dari barang bebas atau limbah. Usaha pembuatan meja kursi dari ban bekas, merupakan jenis industri rumahan (home industry) bagian dari produksi usaha mikro kecil dan menengah (UMKM).

Dengan memberikan motivasi dan pengembangan sumberdaya manusianya, pengusul berharap dapat menggerakkan pelaku home industry tetap eksis dan terus berjuang dalam kondisi ekonomi apapun, karena dengan jumlah penduduk yang padat seperti Indonesia, permasalahan pengangguran bisa diantisipasi dengan mode usaha padat karya yang terwadahi dalam usaha mikro kecil dan menengah (UMKM). Artinya, usaha mikro kecil dan menengah ini dapat menyerap banyak tenaga kerja manusia, karena basic dari usahanya biasanya berupa kerajinan-kerajinan sehingga butuh sentuhan tangan bukan mesin. 
Terkait dengan home industry berbahan baku barang bekas, jika dapat diberdayakan, selain dapat mengurangi angka pengangguran, meningkatkan ekonomi masyarakat juga dapat menjadi solusi mengurangi volume sampah di masyarakat. Bagaimanapun peermasalahan sampah juga menjadi tanggung jawab masyarakat untuk dapat menangani dengan baik, dengan cara mengelola sampah dengan tepat.

\section{KESIMPULAN DAN SARAN}

Penyuluhan motivasi dan pengembangan SDM untuk meningkatkan kemandirian wirausaha home industry meja kursi dari ban bekas diharapkan dapat meningkatkan motivasi dan pengembangan sumber daya manusianya agar dapat mengembangkan usahanya tidak sebatas menghasilakn 4 (empat) set dalam satu hari dengan dua pekerja, melainkan dapat menyerap tenaga kerja lebih banyak dan mampu memproduksi meja kursi dari ban lebih banyak, sehingga mampu meningkatkan ekonomi masyarakat daerah sekitar. Daur ulang ban bekas menjadi meja kursi atau peralatan yang lain sebenarnya baru salah satu cohtoh pemanfaatan barang bekas, masih banyak yang bisa dilakukan dengan sentuhan kreatif merubah barang bekas menjadi barang bernilai ekonomis asalkan ada kemauan dan kemampuan untuk melakukannya.

Oleh karena itu dengan penyuluhan dengan tema motivasi dan pengembangan sumberdaya manusia untuk meningkatkan kemandirian wirausaha ini dimaksudkan dapat memberikan motivasi bagi masyarakat untuk meningkatkan kemampuannya dan berkarya sehingga mendatangkan manfaat bagi dirinya dan masyarakat sekitar.

\section{DAFTAR PUSTAKA}

Gunartin, Soffi, Feb Amni, Pusat Kegiatan Belajar Masyarakat Sebagai Tempat Alternatif Menumbuhkan Kemandirian Wirausaha Warga Belajar (Studi pada PKBM Insan Karya Pamulang Tangerang Selatan, Jurnal PEKOBIS Volume 3 Nomor 2 Oktober 2018

Mankiw, (2006). Principles of Economic, $3^{\text {rd }}$ Edition. Salemba Empat. Jakarta. Chaplin,(2011). Kamus lengkap Psikologi. Raja Grafindo Persada. Jakarta Kasali, (2008). Wirausaha Muda Mandiri. Gramedia Pustaka Utama Jakarta Hasibuan, (2017). Manajemen Sumber Daya Manusia (Edisi Revisi Cetakan ke 8). Bumi Aksara. Jakarta.

Sunarsi, D., Dkk. (2019). Penyuluhan Wirausaha Home Industry Untuk Meningkatkan Ekonomi Keluarga Dengan Daur Ulang Barang Bekas. Jurnal Pengabdian pada Masyarakat BAKTIMAS, 1(4), 188-193. 